\title{
Extraction and characterization of bio-effectors from agro-food processing by-products as plant growth promoters
}

\author{
Ziad Al Chami ${ }^{1 *}$, Deaa Alwanney ${ }^{1}$, Sandra Angelica De Pascali ${ }^{2}$, Ivana Cavoski ${ }^{1}$ and Francesco Paolo Fanizzi ${ }^{2^{*}}$
}

\begin{abstract}
Background: Recently, a novel concept 'bio-effectors' rose on to describe a group of products that are able to improve plant performance rather than fertilizers. Agro-food processing residues and by-products potentially represent important sources of bio-effectors but they are currently not properly taken in consideration. To fulfill this gap, in these study, three food processing by-products: (i) brewers' spent grain, (ii) fennel processing residues, and (iii) lemon processing residues were chosen as bio-effector candidates. Raw materials were chemically characterized, and green extraction methodology was optimized by using water, ethanol, and their mixture based on the extraction yields. Aqueous extracts were used for seed germination bioassays on Lepidium sativum seeds to evaluate their potential bioactivities. Thereafter, the extracts were chemically characterized and metabolites were detected by 1D and 2D NMR spectroscopy.

Results: Results are summarized as follows: (i) raw materials showed an interesting nutritional content; (ii) aqueous extraction resulted higher yield more than other used solvent; (iii) at high solvent extraction ratio, aqueous extracts were not phytotoxic but enhanced seed germination and root elongation; (iv) all aqueous extracts are differently rich in nutrients, amino-acids, sugars, and other low molecular weight molecule compounds.
\end{abstract}

Conclusions: This study confirmed that efficient and simple recovery of bioactive compounds other than nutrients from agro-food processing by-products appear to be the new frontier in their valorization.

Keywords: Bio-effectors; By-product; Barley; Fennel; Lemon; Green extraction; Nuclear magnetic resonance (NMR)

\section{Background}

Soil fertility is considered, after water, the second most limiting factor for agricultural production. The management of soil fertility is facing problems due to the limited availability of organic fertilizer from sustainable sources, together with high prices of the available one, particularly in organic and integrated agriculture. Farmer dependence and reliance on nonrenewable resource, such as phosphorus, which will be depleted within next 50 to 100 years [1], make alternative plant nutrition strategies more urgent. Numerous researcher studies were focused to find environmental-friendly and sustainable sources of nutrients, and different plant growth promoters either synthesized or naturally-derived were tested. Recently,

\footnotetext{
*Correspondence: alchami@iamb.it; fp.fanizzi@unisalento.it

${ }^{1}$ CIHEAM - Istituto Agronomico Mediterraneo di Bari (IAMB), Via Ceglie 9, 70010 Valenzano, BA, Italy

${ }^{2}$ Dipartimento di Scienze e Tecnologie Biologiche ed Ambientali, Università del Salento, Centro Ecotekne strada provinciale Lecce Monteroni, 73100 Lecce, LE, Italy
}

\section{Springer}

(c) 2014 Al Chami et al.; licensee Springer. This is an Open Access article distributed under the terms of the Creative Commons Attribution License (http://creativecommons.org/licenses/by/4.0), which permits unrestricted use, distribution, and reproduction in any medium, provided the original work is properly credited. a novel concept of 'bio-effectors' which describes products that are able to improve plant performances other than fertilizers rose on. Bio-effectors promote plant growth through enhancing or altering biological activity in the soil/plant system [2].

The most common bio-effector present in the market with a considerable amount produced annually ( 15 million metric tons) is seaweeds extract, although its collection and handling is difficult [3]. Another one is humic substances that are also produced intensively from lignite coal which is a nonrenewable source [4]. This indicates the importance of searching and studying new bio-effectors extracted from sustainable sources. New candidates could be agro-food residues and by-products because they may contain bioactive compounds like proteins, sugars and lipids, and specific aromatic and aliphatic compounds. In addition, they are low-cost and abundant materials. 
Therefore, valorization of agro-food processing residues is receiving increased attention and interest [5]. New green extraction technologies like green extraction by using nonhazardous solvents aside from minimizing energy consumption are one of the main purposes that attract attention today [6]. The design of green and nonconventional extraction methods is currently a hot research topic in the multidisciplinary area of applied chemistry, biology, and technology.

Technology platform of the European Union (EU) enterprise provided a 2025 vision of strategic research priorities for organic researches. Bio-effectors cover the eco-functional intensification principles of increasing agricultural productivity by improving existing natural processes [7]. EU regulation No. 834 authorized the use of plant derived materials, products, and by-products of plant origin (such as oilseed cake meal, cocoa husks, and malt culms) for fertilizers in organic agriculture [8]. Moreover, lack of wide-range fertilizer options and authorized compounds like biopesticides in organic agriculture are the main driving force of this research. In fact, the available commercial fertilizers in organic farming are not comparable for their efficiency, solubility, and prices with those in conventional farming.

Therefore, authorized efficient products, economically available for the farmer, able to enhance plant growth and soil nutrients availability are needed. Such products are necessary where chemicals are prohibited and when crop nutrient demand is high. In this context, to detect new sources of bio-effectors, three common agro-food waste, such as brewers spent grain (BSG), fennel processing residues (FPRs), and lemon processing residues (LPRs), were investigated. They were chosen due to their high availability in the south of Italy. Total amount of lemon produced in Italy is around 570,000 tons year ${ }^{-1}$ mainly used for juice and liquor productions. Lemon production is concentrated in the south of Italy, especially in Campania, Basilicata, and Sicily regions. Lemon harvest starts from February till the end of October according to the varieties. Fennel production is also concentrated in the south of Italy, and FPRs are available in large quantities from October till March. The amount of fennel produced in Italy is around 600,000 tons year ${ }^{-1}$ (data from the National Institute of Statistics (ISTAT) www.istat.it). Beer production in Italy reached 13 million hl year ${ }^{-1}$ recently. More than 150,000 tons of malt and 50,000 tons of other cereals are consumed for beer production (ASSOBIRRA, industrial association for beer and malt production, www.assobirra.it). BSG is therefore available all the year in large quantities; breweries are also distributed all over Italy. Many international breweries are located in Apulia region ad es. Birra Peroni is located in Bari. Accordingly, the main objectives of this work are: (i) to explore some promising bio-effector candidates which can be used in agriculture (namely for organic farming), (ii) to develop more environmentfriendly alternatives for plant nutrition strategies such as green extraction technology applied to agro-food processing residues and by-products, and (iii) to chemically characterize the metabolic profile of the extracts for the chosen materials by using high-resolution nuclear magnetic resonance (NMR) spectroscopy.

\section{Experimental \\ Chemicals}

Deionized water (Elix, Millipore Corporation, Bedford, MA, USA) and ethanol (Puriss p.a., ACS Reagent, St. Louis, MO, USA, absolute alcohol, without additive, $\geq$ 99.8\%), $\mathrm{HNO}_{3}$, and $\mathrm{H}_{2} \mathrm{O}_{2}$ TraceSelect were purchased from Sigma Aldrich, (TraceSelect, Sigma-Aldrich, Steinheim, Germany). Ultrapure water $\left(18.2 \mathrm{M} \Omega \mathrm{cm}^{-1}\right)$ was obtained with a Milli-Q purification system from Millipore (Milli-Q, Millipore Corporation, Bedford, MA, USA).

\section{Raw material preparations}

FPRs were brought from JONICA BIO packaging house (Montescaglioso, MT, Italy). FPRs were composed of unmarketable bulbs, green leaves, and external leaves of bulbs of fennel. LPRs were brought from Solagri ${ }^{\oplus}$ (Solagri ${ }^{\oplus}$, Sant'Agnello di Sorrento, NA, Italy). They consist of juicing pulp pomace, white albedo layer and full lemon fruits which cannot be peeled mechanically. The BSGs of barley were brought from Birra Peroni company (Birra Peroni, Bari, Italy).

Raw materials were chopped manually and air dried in a greenhouse. Materials were turned and mixed for daily aeration to prevent fermentation. Greenhouse temperature did not exceed $35^{\circ} \mathrm{C}$ during the drying period. Then, airdried materials were grinded with a mixer mill and passed through a 1-mm sieve to obtain homogeneous particle sizes. All chemical analysis and extraction were done on the grinded and sieved air-dried materials.

\section{Methods}

\section{Solvent choice and extraction yield determination}

Three solvents (deionized water, ethanol, and a mixture of ethanol: water $1: 1 ; \mathrm{v} / \mathrm{v})$, and three ratios $(1: 10 ; 1: 25$; and 1:50: w/v) with three replications were used for the extraction from BSG, FPR, and LPR, respectively. The substrate/solvent ratios were selected on the basis of the experimental conditions required for a nearly quantitative extraction (higher solvent extraction ratio) and the expected high phytotoxicity at lower solvent extraction ratio. The latter was also confirmed by phytotoxicity tests (see below in the text).

Materials were shacked with solvent for $30 \mathrm{~min}$ in $250 \mathrm{~mL}$ polyethylene bottles. Then centrifugation took place at 6,000 rpm for $10 \mathrm{~min}$ followed by filtration with 
Whatman No. 1 filter paper. An aliquot of the filtered extract was dried at $105^{\circ} \mathrm{C}$ for yield determination according to the following equation [9]:

$$
Y=\frac{D}{V} \times \frac{1}{R} C \times 1000
$$

where $Y$ is the yield (g dry matter in extract / kg airdried raw material), $D$ is the dry matter weight (g) of the extract dried at $105^{\circ} \mathrm{C}, R$ is the extraction ratio, $V$ is the volume of the extract used for drying at $105^{\circ} \mathrm{C}(\mathrm{mL})$, and $C$ is the correction factor calculated by dividing the weight of air-dried raw material on the weight of $105^{\circ} \mathrm{C}$ dried raw material.

The extracts with the highest yield were selected for further tests and analyses.

\section{Seed germination bioassays}

Seed germination bioassays were conducted on Lepidium sativum seeds using aqueous extracts according to the EPA protocol [10] and to the IRSA methods for phytotoxicity bioassays of organic substances [11]. Five different extraction ratios $(1: 10 ; 1: 25 ; 1: 50 ; 1: 100$; and 1:200) for BSG and FPR aqueous extracts, whereas six ratios $(1: 10 ; 1: 25 ; 1: 50 ; 1: 100,1: 200$ and $1: 400 \mathrm{w} / \mathrm{v})$ for LPR bioassays were used. The ratio 1:400 was conducted only for LPR aqueous extract because of its high toxicity. Bioassays were performed in plastic petri dishes with four replicates. Each plastic petri dish contained ten seeds distributed on filter paper moistened with $2 \mathrm{~mL}$ of tested extract. Control was moistened with $2 \mathrm{~mL}$ of deionized water.

Petri dishes were incubated in a growth chamber for $48 \mathrm{~h}$ at temperature $25 \pm 5^{\circ} \mathrm{C}$. The experiment was repeated for FPR and LPR extracts as explained previously but for 144 hours. Germination index was calculated using the following equation:

$$
\mathrm{GI}(\%)=\frac{\mathrm{RL}_{\text {Treatment }} \times \mathrm{GS}_{\text {Treatment }}}{\mathrm{RL}_{\text {Control }} \times \mathrm{GS}_{\text {Control }}}
$$

Where GI is the germination index, RL is the root length, and GS is the number of germinated seed. When the germination index exceeded $60 \%$, the extract is considered not phytotoxic [11] and was selected for the further analyses.

\section{Chemical analysis}

Standard methods have been used for the chemical analyses [12]. In brief, the raw materials, residual humidity, and ash were determined successively in oven at $105^{\circ} \mathrm{C}$ and $550^{\circ} \mathrm{C}$. On the raw materials and on the extracts, total $\mathrm{N}$ was determined by the Kjeldahl method [13]. Total macro- and micronutrient concentrations were determined by wet digestion ( $1 \mathrm{~mL} \mathrm{H}_{2} \mathrm{O}_{2}$ and $5 \mathrm{~mL} \mathrm{HNO}_{3}$ ) using a microwave digestion system (CEM model, MARS
Xpress); the samples were then cooled, diluted with ultrapure water in a 50-mL volumetric flask, filtered through Whatman No. 42 filter papers, and finally measured for their cation content by means of an inductively coupled plasma optical emission spectrometer (ICP-OES; Thermo Electron ICAP 6300 Series). Total P was measured colorimetrically on the mineralized samples by a spectrophotometer (He入ios a UV-vis, UNICAM, Thermo Electron Corporation) at $650 \mathrm{~nm}$ using modified ascorbic acid method [14].

On the extracts, $\mathrm{pH}$ was measured using a $\mathrm{pH}$ meter (Basic 20) with a standard glass electrode (Crison 5050, Barcelona, Spain). Electrical conductivity was determined by a conductometer (XS cond 510). Ash was determined on the extract after drying in the oven at $105^{\circ} \mathrm{C}$, and then samples were transferred in the muffle at $550^{\circ} \mathrm{C}$. Total nitrogen was determined by the Kjeldahl method.

Total phenolic contents of the extracts were assayed according to Folin-Ciocalteu method. An aliquote of $100 \mu \mathrm{l}$ of extracts, calibration solutions, and blank were pipetted into separate test tubes, and $900 \mu \mathrm{L}$ of distilled water was added. After, $200 \mu \mathrm{L}$ of Folin-Ciocalteu reagent were added to each test tube. The mixture was mixed well and allowed to equilibrate. After $5 \mathrm{~min}, 1 \mathrm{~mL}$ of a $10 \%(\mathrm{w} / \mathrm{v})$ sodium carbonate solution was added. The mixture was swirled and put in a temperature bath at $40^{\circ} \mathrm{C}$ for $20 \mathrm{~min}$. Then, the tubes were rapidly cooled and the maximum adsorption was measured at $740 \mathrm{~nm}$

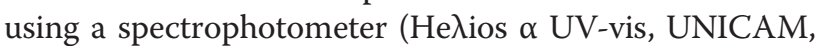
Thermo Electron Corporation). Data were expressed as gallic acid equivalent (GAE) using gallic acid calibration curve. Spectrophotometric analysis that used 2,2-diphenyl-1picrylhydrazyl (DPPH) was performed to determine the antioxidant activities. This assay is based on the ability of the antioxidant to scavenge the radical cation DPPH. Data were expressed as Trolox equivalent antioxidant capacity (TEAC) using Trolox calibration curve. The in vitro antioxidant activities of extracts were performed in the following way: $10 \mu \mathrm{L}$ of extracts were added to $3 \mathrm{~mL}$ of $0.04 \mathrm{mM}$ DPPH ethyl acetate solution and mixed with glass baquet. The samples were kept in the dark for $60 \mathrm{~min}$ at room temperature, and then decrease in absorbance at $517 \mathrm{~nm}$

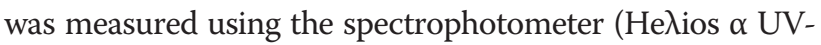
vis, UNICAM, Thermo Electron Corporation). Calibration curve in the range of 0.2/0.4/0.6/1.0/2.0/4.0/6.0 $\mathrm{mmol} \mathrm{L}^{-1}$ were prepared for Trolox.

\section{NMR profiling of BSG, FPR, and LPR extracts}

An amount of $0.321 \mathrm{~g}$ of FPR, $0.270 \mathrm{~g}$ of BSG, and $0.141 \mathrm{~g}$ of LPR dried extracts were dissolved in $1 \mathrm{~mL}$ of $1.2 \mathrm{mM}$ TSP in $\mathrm{D}_{2} \mathrm{O}$ solution, placed in a $5 \mathrm{~mm} \mathrm{NMR}$ tube, and analyzed by multinuclear $\left({ }^{1} \mathrm{H}\right.$ and $\left.{ }^{13} \mathrm{C}\right)$, multidimensional NMR spectroscopy. 
All measurements were performed on a Bruker Avance III NMR spectrometer (Bruker, Karlsruhe, Germany) operating at $400.13 \mathrm{MHz}$ for ${ }^{1} \mathrm{H}$ observation, equipped with a $\mathrm{z}$-axis gradient coil and automatic tuningmatching (ATM).

For each sample, a one-dimensional NOESY experiment (referred to as 1D-NOESY), including a solvent signal saturation during relaxation and mixing time and a spoil gradient, was acquired using 256 free induction decays (FIDs), $64 \mathrm{~K}$ data points, a spectral width of $12.019 \mathrm{~Hz}$, an acquisition time of $3.42 \mathrm{~s}$, a relaxation delay of $4 \mathrm{~s}$, and a mixing time of $10 \mathrm{~ms}$.

2D ${ }^{1} \mathrm{H}$ J-resolved spectra with pre-saturation during relaxation delay were recorded with a spectral width of $4795.396 \mathrm{~Hz}$ on $\mathrm{F} 2$ and $60.020 \mathrm{~Hz}$ on F1, $4 \mathrm{~K}$ data points, 16 FIDs for 128 experiments, and $12 \mathrm{~s}$ repetition delay.

${ }^{1} \mathrm{H}$ COSY spectra with pre-saturation during relaxation delay were acquired with $4 \mathrm{~K}$ data points, a spectral width of $4795.396 \mathrm{~Hz}, 32$ FIDs for 256 experiments, $2 \mathrm{~s}$ repetition delay, and 16 dummy scans.

${ }^{1} \mathrm{H}_{-}{ }^{13} \mathrm{C}$ HSQC and ${ }^{1} \mathrm{H}_{-}{ }^{13} \mathrm{C}$ HMBC NMR spectra were acquired with $4 \mathrm{~K}$ data points, a spectral width of $4795.396 \mathrm{~Hz}$ on ${ }^{1} \mathrm{H}$ and $25156.211 \mathrm{~Hz}$ on ${ }^{13} \mathrm{C}, 16$ FIDs for 256 experiments, $2 \mathrm{~s}$ repetition delay, 16 dummy scans.

The acquisition and processing of spectra were performed using the software TopSpin 2.1 (Bruker Biospin). The FIDs were multiplied by an exponential weighting function corresponding to a line broadening of $0.3 \mathrm{~Hz}$ before Fourier transformation, phasing, and base line correction. All spectra were referenced to the TSP signal $(\delta=0.00 \mathrm{ppm})$, used as internal reference.

The metabolites were assigned on the basis of $2 \mathrm{D}$ NMR spectra analysis (2D ${ }^{1} \mathrm{H}$ J-res, ${ }^{1} \mathrm{H}$ COSY, ${ }^{1} \mathrm{H}-{ }^{13} \mathrm{C}$ HSQC, and HMBC) and comparison with published data $[15,16]$.

\section{Statistical analysis}

Analysis of variance (ANOVA) was carried out, and separation of means was performed using LSD test at $P=0.05$ significance level. LSD test were computed using SAS software version 9 (SAS Institute, Cary, NC). Correlation matrix at $P=0.05$ significance level was performed using XLSTAT 7.5.2 (Addinsoft, Paris, France).

\section{Results and discussion}

\section{Raw material characterization}

Ash content, total nitrogen, macro-nutrients, micronutrient, and total $\mathrm{Cd}$ and $\mathrm{Pb}$ contents of the raw materials (BSG, FPR, and LPR) are shown in Table 1. Ash content in FPR and LPR were almost five times higher than that in BSG. The ash content observed in BSG was approximately half of what Mussatto and Roberto [17] reported.
This result could be due to the variation in raw material in terms of cultivated plant varieties and/or processing procedures (e.g., brewing procedures).

Total $\mathrm{N}$ in the raw materials ranged from 14.5 to $47.9 \mathrm{~g} \mathrm{~kg}^{-1}$ while total P ranged from 1.95 to $4.80 \mathrm{~g} \mathrm{~kg}^{-1}$. In addition to the highest nitrogen content, BSG resulted to be the second higher source of phosphorus. BSG raw material is also rich in total $\mathrm{Cu}$, total $\mathrm{Fe}$, and total $\mathrm{Zn}$. Results of the chemical characterization of BSG was consistent with Khidzir et al. [18] for Mg but differed for $\mathrm{Ca}$ and $\mathrm{P}$. The obtained content of $\mathrm{N}$ and $\mathrm{K}$ is similar to the values previously reported by Gupta et al. [19]. High nitrogen content in the BSG raw material is related to the richness in protein as reported by Kotlar et al. [20].

The highest concentrations of $\mathrm{Ca}$ and $\mathrm{K}$ were found in LPR and FPR raw materials. FPR raw material and FPR extract were rich in $\mathrm{K}$ as previously reported by Bianco et al. [21]. FPR content in macro- and micronutrients was similar to the findings of Muckensturm et al. [22]. FPR raw material was rich in total $\mathrm{P}, \mathrm{Na}, \mathrm{Mn}$, and $\mathrm{Ni}$ contents. Relative high $\mathrm{Na}$ content of FPR was estimated to be 10 times higher than LPR and 100 times higher than BSG. Fe was found to be the most abundant microelement in all materials with content ranged from 114 to $169 \mathrm{mg} \mathrm{kg}^{-1}$.

LPR was the lowest source of almost all analyzed nutrients except for Ca. Low nutrient content in LPR was also previously reported by $\mathrm{Su}$ and Horvat [23] and confirmed by USDA National Nutrient Database for Standard Reference [24].

Total $\mathrm{Cd}$ and $\mathrm{Pb}$ contents resulted below the limitation of hazardous substances required by the European regulations (EU 'eco-label'; Commission Decision 2006/ 799/EC) [25] for soil improvers.

\section{Solvent choice and extraction yield determination}

Figure 1 shows the extraction yields for BSG, FPR, and LPR at 1:10, 1:25, and 1:50 solvent extraction ratios. Aqueous extracts gave the highest yields for FPR and LPR, while no significant differences were observed among different solvents for BSG. Generally, EtOH extract gave the lowest yield in comparison to the aqueous and $\mathrm{EtOH}-\mathrm{H}_{2} \mathrm{O}$ mixture extract. However, yield obtained by EtOH- $\mathrm{H}_{2} \mathrm{O}$ mixture was significantly lower than the yield obtained by water for both FPR and LPR. In general, and independently the solvent used, when the solvent extraction ratio increased, the extraction yield did not increase significantly. Our results showed that when the content of ethanol in the solvent increases, the total extraction yield decreases for FPR and LPR while no differences in yield was found in BSG. This may be due to the higher polarity of water in comparison to ethanol [26] and to the higher polar metabolites content in FPR and LPR. In our study, aqueous extraction resulted in 
Table 1 Ash content, total macro-and micronutrients, Cd, and Pb contents in raw materials (BSG, FPR, and LPR)

\begin{tabular}{|c|c|c|c|c|c|c|c|c|c|c|c|c|c|c|}
\hline \multirow[t]{2}{*}{ Raw materials } & Ash & $\begin{array}{c}\text { Total } \\
\mathrm{N}\end{array}$ & $\begin{array}{c}\text { Total } \\
\text { P }\end{array}$ & $\begin{array}{c}\text { Total } \\
\text { Ca }\end{array}$ & $\begin{array}{c}\text { Total } \\
\text { K }\end{array}$ & $\begin{array}{c}\text { Total } \\
\text { Mg }\end{array}$ & $\begin{array}{c}\text { Total } \\
\mathrm{Na}\end{array}$ & $\begin{array}{c}\text { Total } \\
\mathrm{Cu}\end{array}$ & $\begin{array}{l}\text { Total } \\
\mathrm{Fe}\end{array}$ & $\begin{array}{c}\text { Total } \\
\text { Mn }\end{array}$ & $\begin{array}{c}\text { Total } \\
\mathrm{Ni}\end{array}$ & $\begin{array}{c}\text { Total } \\
\mathrm{Zn}\end{array}$ & $\begin{array}{c}\text { Total } \\
\text { Cd }\end{array}$ & $\begin{array}{c}\text { Total } \\
\mathrm{Pb}\end{array}$ \\
\hline & $\%$ & $\mathrm{~g} \mathrm{~kg}^{-1}$ & $\mathrm{~g} \mathrm{~kg}^{-1}$ & $\mathrm{~g} \mathrm{~kg}^{-1}$ & $\mathrm{~g} \mathrm{~kg}^{-1}$ & $\mathrm{~g} \mathrm{~kg}^{-1}$ & $\mathrm{~g} \mathrm{~kg}^{-1}$ & $\mathrm{mg} \mathrm{kg}^{-1}$ & $\mathrm{mg} \mathrm{kg}^{-1}$ & $\mathrm{mg} \mathrm{kg}^{-1}$ & $\mathrm{mg} \mathrm{kg}^{-1}$ & $\mathrm{mg} \mathrm{kg}^{-1}$ & $\mathrm{mg} \mathrm{kg}^{-1}$ & $\mathrm{mg} \mathrm{kg}^{-1}$ \\
\hline BSG & $4.10 \pm 0.1$ & $47.9 \pm 0.7$ & $4.79 \pm 0.4$ & $4.41 \pm 0.5$ & $0.51 \pm 0.0$ & $1.63 \pm 0.1$ & $0.07 \pm 0.0$ & $14.3 \pm 1.4$ & $169 \pm 13$ & $37.3 \pm 2.1$ & $2.5 \pm 0.3$ & $97.5 \pm 7.9$ & $<0.01$ & $0.28 \pm 0.06$ \\
\hline FPR & $20.4 \pm 0.8$ & $30.9 \pm 1.0$ & $4.80 \pm 0.8$ & $6.67 \pm 0.7$ & $33.4 \pm 1.1$ & $1.58 \pm 0.1$ & $7.00 \pm 0.2$ & $8.94 \pm 1.5$ & $137 \pm 21$ & $75.5 \pm 6.7$ & $5.1 \pm 0.8$ & $26.4 \pm 2.1$ & $<0.01$ & $0.38 \pm 0.09$ \\
\hline LPR & $20.1 \pm 0.5$ & $14.5 \pm 0.6$ & $1.95 \pm 0.3$ & $10.3 \pm 0.5$ & $9.04 \pm 0.8$ & $1.02 \pm 0.1$ & $0.70 \pm 0.0$ & $5.52 \pm 1.0$ & $114 \pm 15$ & $5.54 \pm 0.6$ & $1.8 \pm 0.1$ & $12.8 \pm 1.0$ & $<0.01$ & $0.19 \pm 0.04$ \\
\hline
\end{tabular}

Values reported are average of three replicates \pm standard deviation.

BSG, brewers spent grain; FPR, fennel processing residues; LPR, lemon processing residues. 


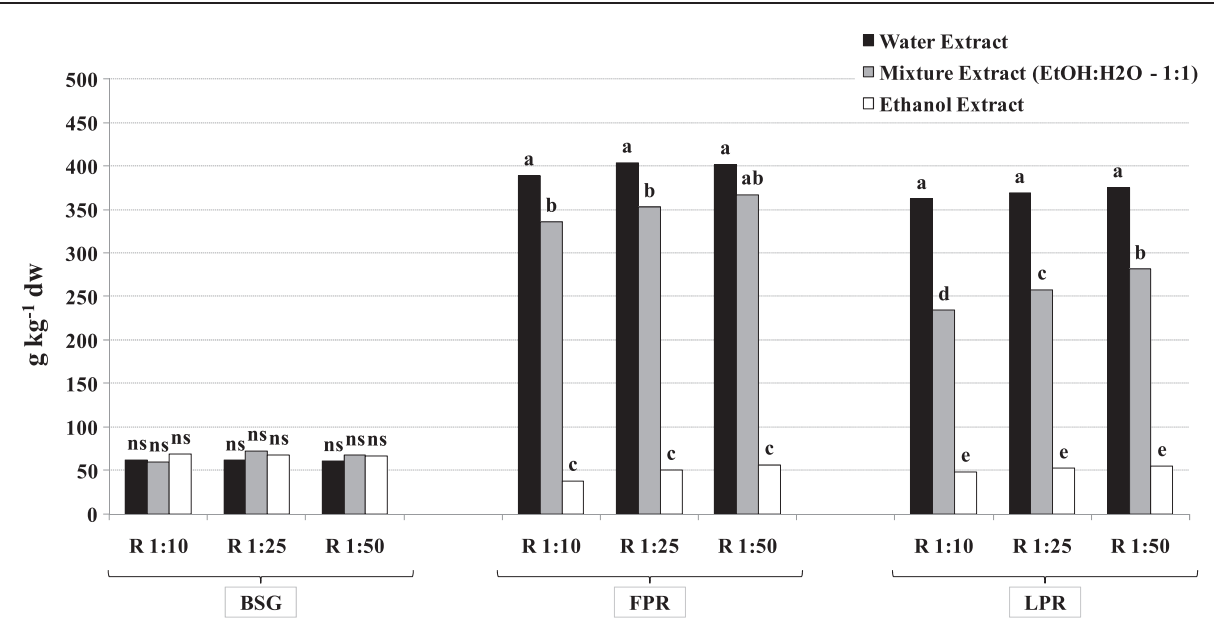

Figure 1 Extraction yield of BSG, FPR, and LPR at 1:10, 1:25, and 1:50 extraction ratios. Means with different letters within the same raw materials indicate the significant difference between values at $P<0.05$ (LSD Fisher's test). NS not significant, $R$ ratio.

higher yield than the mixture of $\mathrm{EtOH}-\mathrm{H}_{2} \mathrm{O}$ and therefore only aqueous extracts were used for further tests.

In BSG extracts, changing the ratio and/or the solvent did not affect obtained yields. In our study, applying different solvent extraction ratios did not strongly change the yields regardless the solvent or material and that was in agreement with Kalia et al. [27].

In FPR extracts, yields were not affect by changing the solvent extraction ratio, while the solvent used had significant effect. The extraction yields for the different solvents ranked as follows: $\mathrm{EtOH}<\mathrm{EtOH}-\mathrm{H}_{2} \mathrm{O}<\mathrm{H}_{2} \mathrm{O}$. The yield of the aqueous extract was almost eight times higher than for the EtOH extracts. The high extraction yield obtained from FPR could be due to the richness in high molecular weight polysaccharide as reported by Taie et al. [28]. On the other hand, Leal et al. [29] has estimated the aqueous extraction yield of FPR by $16.8 \%$, while it exceeded $45 \%$ in this study. The different FPR yields can be explained by the differences in extraction procedures such as temperature, extraction time, and ratios. Our results varied also when compared to Il-Suk et al. [30] who obtained an extraction yield equal to $11.38 \%$. Taie et al. [28] found significant differences in FPR extraction yield when different solvents and/or ratios were applied and these results are similar to our findings.

In LPR extract, similar results as FPR extracts were obtained. In fact, aqueous extracts gave the same yield when 1:10, 1:25, and 1:50 extraction ratios were applied. Similar results were obtained when $\mathrm{EtOH}$ was used. Conversely, the yield of LPR EtOH- $\mathrm{H}_{2} \mathrm{O}$ extracts varied significantly when different ratios were used. The yield was in the order of 1:10 $<1: 25<1: 50$ for LPR EtOH- $\mathrm{H}_{2} \mathrm{O}$ extracts. The yield of LPR extraction using EtOH- $\mathrm{H}_{2} \mathrm{O}$ extraction was equal to $135 \mathrm{~g} \mathrm{~kg}^{-1}$ of fresh peel as determined by Kang et al. [31]. The differences between our study and the previous studies could be due to the higher percentage of $\mathrm{EtOH}$ used in the mixture. The low yield of ethanolic extraction of LPR was confirmed by Zia-ur [32]. However, the extraction yield can be improved by other assistant methods such as ultrasounding method [33].

Generally, the compounds obtained by organic solvent such as EtOH are different from those obtained by the aqueous extraction. Tsibranska et al. [34] found that the organic solvents like ethanol can give two times higher content of valuable compounds in the extract. However, aqueous extraction was adopted for many reasons other than the yield. Indeed, there are restrictions in organic solvent use for green extraction technology as well as in organic farming. Moreover, it should be underlined that (i) aqueous extraction is efficient and less expensive in comparison to other solvents, nontoxic, and environmentalfriendly alternative to conventional extraction techniques; (ii) it is easy for both field application and market registration; (iii) organic solvents are phytotoxic for plants and, in addition, extra work is needed to remove them from the extract; (iv) other surfactant (e.g., tween, dimethyl sulfoxide) should be added to redissolve in water compounds extracted with other organic solvents, increasing the cost of the bio-effector; (v) the extraction yields of some bioactive components resulted better in water than ethanol at room temperature [35]; and (vi) the limitation of aqueous extraction can be reduced by increasing the temperature [36] which rises the water polarity [37].

\section{Seed germination bioassays for optimum solvent extraction ratio determination}

Figure 2 shows the germination indexes (GI) after $48 \mathrm{~h}$ of incubation using different aqueous extraction ratios. According to IRSA method [11], GI index below $60 \%$ is an indication of phytotoxic effect, while GI above $60 \%$, is 


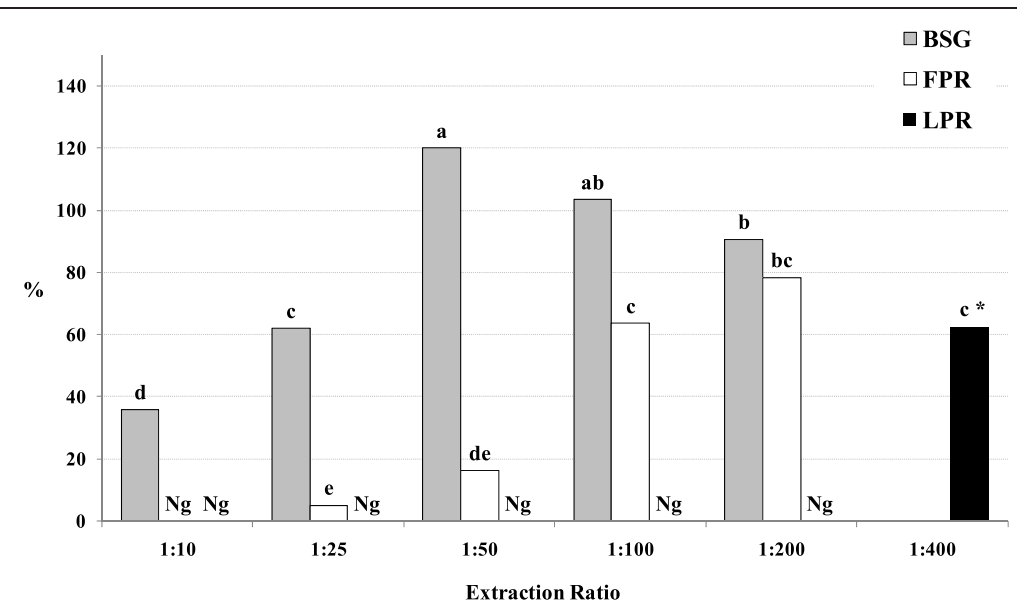

Figure 2 Germination index after $\mathbf{4 8} \mathbf{h}$. Means with different letters indicate significant difference between values at $P<0.05$ (LSD Fisher's test). $\mathrm{Ng}$ no germination. The asterisk denotes that the extraction ratio 1:400 was done only for LPR.

considered not phytotoxic, and there is no harmful risk for plant growth.

The highest GI in each ratio of extraction was obtained with BSG treatment followed by FPR treatment. BSG aqueous extract enhanced seed germination and root growth. In fact, GI index in BSG aqueous extract increased by $20 \%$ in comparison to control at 1:50 extraction ratio. Seeds did not germinate in the FPR aqueous extract at 1:10 extract ratio, and GI increased when the solvent extraction ratio increased. LPR was very toxic and no seed germination was observed at 1:10, $1: 25,1: 50,1: 100$, or 1:200 extraction ratios while GI reached $62 \%$ at $1: 400$ ratio.

Due to the higher toxicity of FPR and LPR, the related experiment was repeated for a longer time ( $144 \mathrm{~h}$ ). Figure 3 shows the improvement of GI for FPR and LPR aqueous extract after $144 \mathrm{~h}$ of seed incubations. No germination was registered for LPR extract at 1:25 and 1:50 ratios after
$144 \mathrm{~h}$ and matched the results after $48 \mathrm{~h}$, while slight increase in GI was obtained by LPR at 1:100 ratio (34\%) and 1:200 ratio resulted in GI equal to $66.7 \%$.

In order to understand the effects of the aqueous extracts on the GI, a correlation matrix was determined between $\mathrm{pH}, \mathrm{EC}$, and GI for each aqueous extract. The correlation matrices are shown in Table 2. GI is negatively correlated with EC. Salinity inhibits seed germination due to an osmotic effect or a specific ion toxicity [38]. In addition, $\mathrm{pH}$ influences seed germination. In fact, seed germination is inhibited when $\mathrm{pH}$ is below 5 and completely inhibited when the $\mathrm{pH}$ is below 4 [39]. The correlation between $\mathrm{pH}$ value and GI explains the low germination index obtained from LPR aqueous extract which had the highest acidity. The low GI obtained in FPR when low solvent extraction ratio is adopted could be due to the high EC and to the high total polyphenols which can negatively affect seed germination.

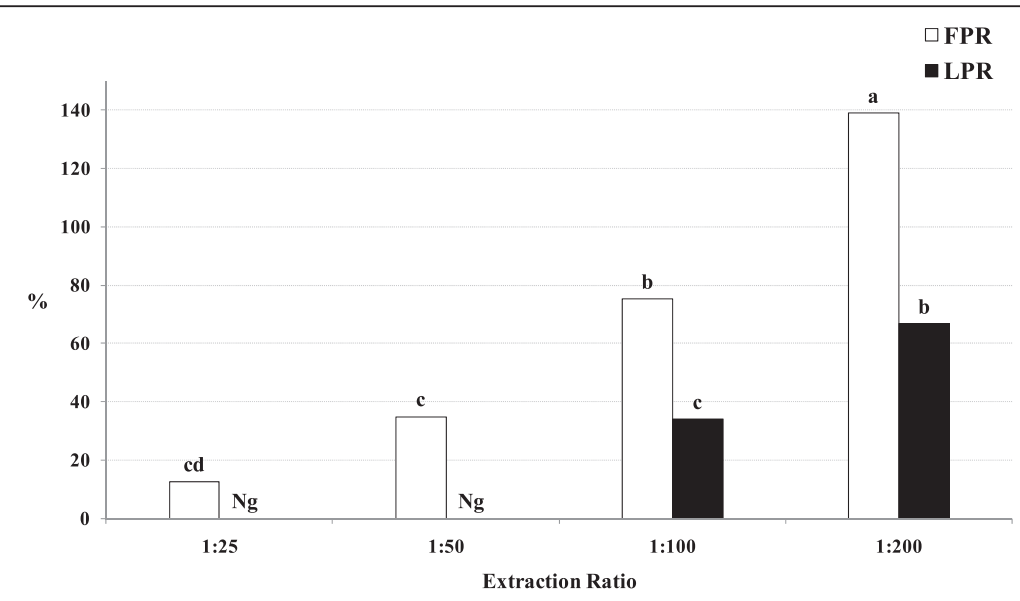

Figure $\mathbf{3}$ Germination index after $\mathbf{1 4 4} \mathbf{h}$. Means with different letters indicate significant difference between values at $P<0.05$ (LSD Fisher's test). Ng no germination. 
Table 2 Correlation matrix between $\mathrm{pH}, \mathrm{EC}$, and $\mathrm{GI}$ (48 and 144 h) for BSG 1:25, FPR 1:100, and LPR 1:200 aqueous extracts

\begin{tabular}{llll}
\hline & & Gl (48 h) & Gl (144 h) \\
\hline BSG & pH & 0.72 & $\mathrm{Nd}$ \\
& EC & $-\mathbf{0 . 8 6}$ & $\mathrm{Nd}$ \\
FPR & $\mathrm{pH}$ & -0.76 & -0.75 \\
& EC & $-\mathbf{0 . 8 5}$ & $-\mathbf{0 . 8 5}$ \\
LPR & pH & $\mathbf{0 . 9 2}$ & $\mathbf{0 . 8 9}$ \\
& EC & -0.40 & -0.71 \\
\hline
\end{tabular}

$\mathrm{Gl}$, germination index at $48 \mathrm{~h}$ and $144 \mathrm{~h} ; \mathrm{BSG}$, brewers spent grain; FPR, fennel processing residues; $\mathrm{LPR}$, lemon processing residues; $\mathrm{Nd}$, not determined. Values in bold indicate significant $P=0.05$ (two-tailed test).

Total polyphenols are relatively high in FPR and LPR extracts in comparison to BSG extract. Total polyphenols are known to have germination inhibitor effect [40].

However, when the toxicity of the extract is low, a retardation in seed germination could be observed. In fact, at higher solvent extraction ratio for FPR and LPR, an increase in germination index at $144 \mathrm{~h}$ test time was observed in comparison to $48 \mathrm{~h}$. No seed germination was observed in LPR extract treatment at 1:200 ratio for the first $48 \mathrm{~h}$ while at $144 \mathrm{~h}$, GI was equal to $66.7 \%$ which is considered the limit to classify the extract as nontoxic. Based on the obtained results, BSG 1:25, FPR 1:100, and LPR 1:200 $(\mathrm{GI}>60 \%)$ were selected for the chemical characterization.

\section{Extract characterization}

Ash content, total nitrogen, macro- and micronutrients, and heavy metal contents of each aqueous extract (BSG 1: 25, FPR 1:100, and LPR 1: 200) are shown in Table 3. The results revealed that all extracts were rich in macroand micronutrients; therefore, the use of these aqueous extracts can have an added value for plant nutrition. The highest EC $\left(0.6 \mathrm{dS} \mathrm{m}^{-1}\right)$ was measured in FPR extract. The lowest $\mathrm{pH}$ value (3.3) was measured in LPR extract. Ash content was highest in FPR in comparison to those in LPR and BSG aqueous extracts. FPR extract was found to be almost the richest source of N, P, and K in comparison to those in LPR and BSG aqueous extracts. BSG extract was slightly higher in total P content than that in FPR extract. BSG extract showed the highest content in total $\mathrm{Ca}$ and $\mathrm{Mg}$. We found the FPR extract to be the richest in total $\mathrm{K}$ content with more than $330 \mathrm{mg} \mathrm{L}^{-1}$. Total Mg content was the highest in BSG extract, and total Fe was the highest in LPR extract. FPR content of total $\mathrm{Na}$ was approximately 13 times higher than those in LPR and BSG contents. The highest concentrations of $\mathrm{K}$, $\mathrm{Cu}, \mathrm{Na}, \mathrm{Ni}$, and $\mathrm{Zn}$ were found in FPR extract. Fe is the most abundant microelement in all three materials with content ranged from 114 to $169 \mathrm{mg} \mathrm{kg}^{-1}$.
Table 3 pH, EC, ash content, total macro- and micronutrients, total $\mathrm{Cd}$, total $\mathrm{Pb}$, total polyphenols and antioxidant activity content in BSG 1:25 FPR 1:100 and LPR 1:200 aqueous extracts

\begin{tabular}{|c|c|c|c|c|}
\hline $\begin{array}{l}\text { Aqueous } \\
\text { extracts }\end{array}$ & & BSG 1:25 & FPR 1:100 & LPR 1:200 \\
\hline $\mathrm{pH}$ & & $5.5 \pm 0.1$ & $5.5 \pm 0.2$ & $3.3 \pm 0.1$ \\
\hline EC & $\mathrm{dS} \mathrm{m}^{-1}$ & $0.2 \pm 0.0$ & $0.6 \pm 0.1$ & $0.5 \pm 0.0$ \\
\hline Ash & $\%$ & $18.5 \pm 0.2$ & $25.0 \pm 1.1$ & $9.3 \pm 0.3$ \\
\hline Total N & & $40.0 \pm 0.4$ & $157 \pm 10$ & $10.0 \pm 0.2$ \\
\hline Total P & & $47.2 \pm 0.2$ & $43.6 \pm 0.3$ & $3.78 \pm 0.2$ \\
\hline Total K & & $19.4 \pm 1.8$ & $330 \pm 8.7$ & $50.1 \pm 4.5$ \\
\hline Total Ca & & $58.3 \pm 0.4$ & $8.22 \pm 0.55$ & $34.7 \pm 2.7$ \\
\hline Total Mg & & $34.3 \pm 0.40$ & $5.41 \pm 0.8$ & $5.49 \pm 0.60$ \\
\hline Total Na & & $5.44 \pm 1.1$ & $72.0 \pm 2.3$ & $5.46 \pm 0.48$ \\
\hline Total Cu & $m g L^{-1}$ & $0.05 \pm 0.01$ & $0.11 \pm 0.00$ & $0.05 \pm 0.00$ \\
\hline Total Fe & & $0.44 \pm 0.08$ & $0.43 \pm 0.10$ & $0.55 \pm 0.04$ \\
\hline Total Mn & & $0.32 \pm 0.01$ & $0.17 \pm 0.00$ & $0.03 \pm 0.00$ \\
\hline Total Ni & & $0.03 \pm 0.01$ & $0.06 \pm 0.00$ & $0.02 \pm 0.00$ \\
\hline Total Zn & & $0.18 \pm 0.05$ & $0.27 \pm 0.06$ & $0.27 \pm 0.05$ \\
\hline Total Cd & & $<0.005$ & $<0.005$ & $<0.005$ \\
\hline Total Pb & & $0.01 \pm 0.00$ & $0.01 \pm 0.00$ & $0.01 \pm 0.00$ \\
\hline $\begin{array}{l}\text { Total } \\
\text { polyphenols }\end{array}$ & $\mathrm{g} \mathrm{kg}^{-1}$ & $\begin{array}{l}10.57 \pm \\
1.96^{c}\end{array}$ & $\begin{array}{l}57.88 \pm \\
5.61^{a}\end{array}$ & $\begin{array}{l}49.54 \pm \\
3.13^{b}\end{array}$ \\
\hline $\begin{array}{l}\text { Antioxidant } \\
\text { activity }\end{array}$ & $\mathrm{m}_{-1} \mathrm{M}$ trolox $\mathrm{L}$ & $1.81 \pm 0.31^{c}$ & $5.55 \pm 1.01^{a}$ & $3.77 \pm 0.44^{b}$ \\
\hline
\end{tabular}

Values reported are average of three replicates \pm standard deviation. Within same row, means with different letters $(a, b, c)$ indicate significant difference between values at $P<0.05$ (LSD Fisher's test).

BSG, brewers spent grain; FPR, fennel processing residues; LPR, lemon processing residues.

Total $\mathrm{Pb}$ content in all extract was around $0.01 \mathrm{mg} \mathrm{L}^{-1}$ which is considered very low, while total $\mathrm{Cd}$ content was below the instrument detection limit $\left(<0.01 \mathrm{mg} \mathrm{L}^{-1}\right)$.

Total polyphenols and antioxidant activity are shown in the Table 3. Extracts of studied materials revealed different amounts of polyphenols: 10.6, 57.9 and $49.5 \mathrm{~g} \mathrm{~L}^{-1}$ in BSG, FPR, and LPR, respectively. Aqueous extract obtained from FPR showed high polyphenolic content and antioxidant activity. Total polyphenols content in BSG aqueous extract was significantly lower than FPR and LPR aqueous extract. FPR extract showed an important DPPH scavenging ability exhibited by the highest antioxidant activity $\left(5.5 \mathrm{mM}\right.$ trolox $\left.\mathrm{L}^{-1}\right)$. LPR antioxidant activity was much higher than BSG's.

The low content of total polyphenols observed in BSG extract may be due to their weak solubility in water. Both hydrolysis and saponification with $\mathrm{NaOH}$ are the suitable extraction techniques of BSG polyphenols [41]. Methanolic extraction was also used for quantification and extraction of polyphenolic compounds from BSG by Naczk and Shahidi [42]. The high polyphenolic compounds 
observed in FPR is probably the reason for its high antioxidant activity [43]. Total polyphenols content measured in this study $\left(57.9 \mathrm{~g} \mathrm{~kg}^{-1}\right)$ is in accordance with Munir et al. [44] but was higher than the total polyphenols content observed by Taie et al. [28] (31.94 $\left.\mathrm{g} \mathrm{kg}^{-1}\right)$. Parejo et al. [45] referred the antioxidant activity of FPR to some compounds such as caffeoylquinic acid, rosmarinic acid, and kaempferol-3-O-glucoside. The high antioxidant activity of LPR extract was indicated by the strong scavenging ability of free radicals, and nitrites [46]. The polyphenolic content of the aqueous solution of other types of citrus peel powders seems to give different value $\left(3.5 \mathrm{~g} \mathrm{~kg}^{-1}\right)$ [31] in comparison with our result $\left(49.5 \mathrm{~g} \mathrm{~kg}^{-1}\right)$.

High-resolution NMR spectroscopy represents a potentially powerful tool for plant metabolite analysis [47]. This technology has been previously utilized to profile metabolites in clinical samples $[48,49]$ but also to account for the metabolic changes that occur during fermentation and/or production processes, and to evaluate the quality of food and beverages such as oil and wine [50-52]. The main advantage of NMR spectroscopy, as well as the sample preparation, is that it is not
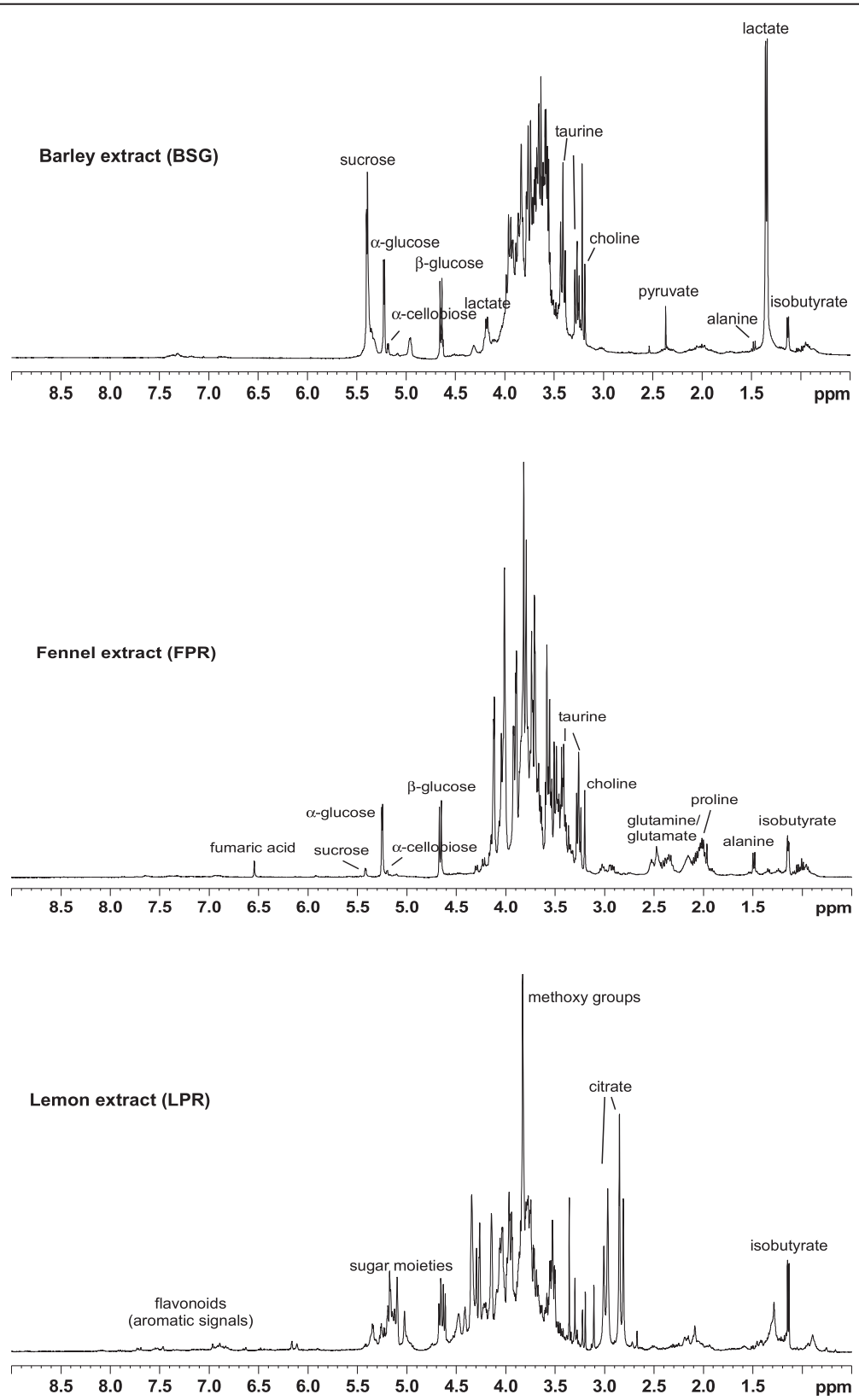

Figure $4{ }^{1} \mathrm{H}$ NMR spectra of FPR, BSG, and LPR extracts in $\mathrm{D}_{2} \mathrm{O}$. 
discriminatory, unlike certain mass spectrometry methods that rely on the prior separation and/or derivatization of metabolites. In this way, all compounds such as carbohydrates, amino acids, organic and fatty acids, amines, esters, ethers, and lipids, which are present in a sample, could be simultaneously detected and investigated by NMR spectroscopy. Thus, NMR spectra of raw material extracts have the potential to provide a relatively unbiased fingerprint, containing the signals of the metabolites present in the solution.

${ }^{1} \mathrm{H}$ NMR spectra of extracts showed several signals attributed to amino acids, sugars, and low molecular weight compounds (Figure 4). They were assigned by comparison with published data [15] on the basis of analysis of $2 \mathrm{D}$ NMR spectra $\left(2 \mathrm{D}{ }^{1} \mathrm{H}\right.$ J-res, ${ }^{1} \mathrm{H}$ COSY, ${ }^{1} \mathrm{H}_{-}{ }^{13} \mathrm{C}$ HSQC and $\mathrm{HMBC})$. The metabolites list with their chemical shifts $(\delta)$, and the presence detected in each extract are reported in Table 4. Although most metabolites are present in all extracts, there are several differences in their concentration. Interestingly, in the FPR extract, the preponderant metabolites are $\alpha$ and $\beta$ glucose whereas sucrose and lactate are the most abundant in the BSG extract. In the LPR extract, due to the presence of high level of citrate, the $\mathrm{pH}$ was very acidic producing a de-shielding of most $\mathrm{pH}$ sensitive signals. Moreover, the lemon extract shows a very high singlet at $3.83 \mathrm{ppm}$, attributed to the methoxy moieties of flavonoids.

Concerning NMR profiling results, important differences were noticed among extracts for leucine, proline, glutamine, and methionine. The aromatic signal resulted by flavonoids was observed only in LPR extract.

Lactic acid present in all aqueous extracts is known to have positive effects on plant growth as well as on crop yield and quality, especially under stress conditions [53]. This behavior is due to the forming of stable bonds with several metal ions [54]. Furthermore, the presence of fumaric acid in BSG and FPR extracts offers an explanation for their effects. Fumaric acid is required for rapid nitrogen assimilation, also as a temporary carbon sink for photosynthate [55].

In BSG extract, $\alpha$ and $\beta$-glucose [56] and choline [57] were previously reported. On the contrary, methoxy group and proline mentioned in the study of Gupta et al. [19] and Huige [57], respectively, were not detected in our samples. Santos et al. [58] suggested that barley variety along with malting conditions and the type of additives in the brewing process can affect the BSG content. However, other possible explanation could be related to the sensitivity of applied NMR techniques. Moreover, BSG extract has a special characteristic. Changes occur during uncompleted germination stage of barley, during the brewing process, include increment in bioactive compounds [59]. Those changes could play an important role during seed germination. Pyruvate was detected only in the BSG extract and it is considered the direct tool by
Table 4 Metabolites observed in the fennel BSG, FPR, and LPR extracts and their ${ }^{1} \mathrm{H}$ NMR chemical shifts $(\delta)$

\begin{tabular}{|c|c|c|c|c|}
\hline Metabolites & BSG & FPR & LPR & $\delta$ \\
\hline Isoleucine & $x$ & $x$ & & $0.93[7]^{\mathrm{a}}(\mathrm{t}), 1.00[7](\mathrm{d})$ \\
\hline Leucine & $x$ & & & 0.94 [7] (d), 0.96 [7] (d) \\
\hline Valine & $x$ & $x$ & & $\begin{array}{l}0.98[7](d), 1.03[7](d), 2.26 \\
(m)\end{array}$ \\
\hline Isobutyrate & $x$ & $x$ & $x$ & $1.13[6.5](d)$ \\
\hline 3-Hydroxybutirate & $x$ & & & $1.21[6.4](d)$ \\
\hline Lactate & $x$ & $x$ & $x$ & $1,35[7](d), 4.12[7](q)$ \\
\hline Alanine & $x$ & $x$ & $x$ & $1.48[7.2](d), 3.78[7.2](q)$ \\
\hline Proline & & $x$ & & $\begin{array}{l}2.03(\mathrm{~m}), 2.36(\mathrm{~m}), 3.36(\mathrm{~m}), \\
4.12(\mathrm{~m})\end{array}$ \\
\hline Glutamate & & $x$ & & $2.00(\mathrm{~m}), 2.08(\mathrm{~m}), 2.35(\mathrm{~m})$ \\
\hline Glutamine & & $x$ & & $2.13(\mathrm{~m}), 2.41(\mathrm{~m}), 3.77(\mathrm{~m})$ \\
\hline Methionine & & & $x$ & $2.15(s)$ \\
\hline Pyruvate & $x$ & & & $2.36(s)$ \\
\hline Methylamine & $x$ & & $x$ & $2.54(\mathrm{~s})$ \\
\hline Dimethylamine & $x$ & & $x$ & $2.72(\mathrm{~s})$ \\
\hline Trimethylamine & $x$ & & $x$ & $2.81(\mathrm{~s})$ \\
\hline Asparagine & & $x$ & & $2.89(\mathrm{~m}), 2.96(\mathrm{~m})$ \\
\hline Choline & $x$ & $x$ & $x$ & $3.20(\mathrm{~s})$ \\
\hline Taurine & $x$ & $x$ & & $3.26(\mathrm{t}), 3.41(\mathrm{t})$ \\
\hline Methoxy group & & & $x$ & $3.83(\mathrm{~s})$ \\
\hline$\beta$-Cellobiose & $x$ & $x$ & & $4.48[8](d)$ \\
\hline$\beta$-Galactose & & & $x$ & $4.52[7.8](d)$ \\
\hline$\beta$-Glucose & $x$ & $x$ & $x$ & $4.65[7.9](d)$ \\
\hline a-Cellobiose & $x$ & $x$ & & $5.20[3.6](d)$ \\
\hline a-Glucose & $x$ & $x$ & $x$ & $5.25[3.7](d)$ \\
\hline a-Galactose & & & $x$ & $5.27[3.7](d)$ \\
\hline Sucrose & $x$ & $x$ & $x$ & $5.42[3.8](d)$ \\
\hline Fumaric acid & $x$ & $x$ & & $6.56(s)$ \\
\hline Tyrosine & $x$ & $x$ & $x$ & $6.88[8.6](d), 7.17[8.6](d)$ \\
\hline Phenylalanine & $x$ & $x$ & & $7.33(\mathrm{~m}), 7.38(\mathrm{~m}), 7.43(\mathrm{~m})$ \\
\hline Formiate & & & $x$ & $8.43(s)$ \\
\hline $\begin{array}{l}\text { Flavonoids (aromatic } \\
\text { signals) }\end{array}$ & & & $x$ & 6.5 to 9.0 range \\
\hline
\end{tabular}

${ }^{a}$ Values of $J_{H, H}$ [square brackets] are given when assignable. BSG, brewers spent grain; FPR, fennel processing residues; LPR, lemon processing residues.

which gibberellin regulates the growth [60]. Moreover, Yu et al. [61] explained that pyruvate is converted in plant cell to acetyl-CoA and NADH for energy production (tricarboxylic acid cycle). Therefore the plant metabolome might be affected by such processes.

NMR profile of FPR extract showed similar results to those demonstrated by Muckensturm et al. [22]. The flavonoids observation in LPR extract was reported by Mandalari et al. [62]. LPR carbohydrates and organic acids were described also by Poli et al. [63]. Organic 
acids present in LPR extracts had also an important impact on plant growth. Starting from growth media, organic acids carry negative charges which allow to make cations complexation and anions displacement [64]. Organic acids can flow across lipid bilayer of hairy root cells [65]. Citric acid of LPR is an important component of the stress response and for plant growth [66].

Finally, the aqueous extracts are rich in several low molecular weight organic compounds, and can be good candidates to be tested as bio-effectors in a more detailed study.

\section{Conclusions}

Potential and practical contributions of tested raw materials aqueous extracts as bio-effector candidates were discussed. The agro-food processing residues and their extracts studied above showed an interesting content, either at nutritional or biochemical level, and could be used as plant growth promoter. They are differently rich in nutrients, amino-acids, sugars, and low molecular weight molecules as demonstrated by the chemical analysis and NMR metabolic profiling. Furthermore, aqueous extraction resulted higher yield with respect to other used solvent. Water, safe and less expensive than other organic solvents, is effective for BSG, FPR, and LPR extractions under different extraction ratios. In addition, aqueous extracts were not phytotoxic but enhanced seed germination at higher solvent extraction ratio. BSG aqueous extract enhanced seed germination and root growth. FPR aqueous extract, at low solvent extraction ratio, showed low GI which increased when the solvent extraction ratio increased. LPR was very toxic at low solvent extraction ratio; therefore, higher solvent extraction ratios are required for the use of this product.

Finally, the reuse of agro-food processing residues as a potential source of bio-effectors suggests a rethinking of plant nutritional management in a sustainable manner. Bio-effectors can be applied in both low input (organic and integrated) and high input (conventional) types of agriculture. According to our results, we suggest that aqueous extracts could be used even in organic farming. However, further studies including comparison with other commercial plant growth promoters and toxicity studies on the microbial soil community should be conducted to evaluate the effects of suggested bio-effectors on the soil/plant system.

\section{Competing interests}

The authors declare that they have no competing interests.

\section{Authors' contributions}

ACZ has made the research protocol, conception and design, analysis of macro- and micronutrients, phytotoxicity test, and extraction yields. He also participated in the other data acquisition and analysis and the whole data interpretation. He has also made the manuscript drafting. AD is the Master's Student who followed the work to obtain his Master Degree. DPSA carried out the NMR analysis and the NMR result writings. Cl has made substantial contributions to the conception and design, carried out the total polyphenols analysis and antioxidant activities, and helped to draft the manuscript and data interpretation. FFP has made substantial contributions to the conception and design, manuscript revising and has given the final approval of the version to be published. All authors read and approved the final manuscript.

\section{Acknowledgments}

The authors want to acknowledge the Mediterranean Agronomic Institute of Bari (MAIB) for supporting this research work and the Department of Biotechnology and Environmental Science, University of Salento for the NMR analysis. The authors want to thank JONICA BIO packaging house, Montescaglioso, Matera, Italy, for providing fennel processing residues; Solagri , Sant' Agnello di Sorrento, Napoli, Italy for providing the lemon processing residues; and Birra Peroni company, Bari, Italy, for providing the brewers' spent grains.

Received: 16 July 2014 Accepted: 20 September 2014

Published online: 24 October 2014

\section{References}

1. Cordell D, Drangert JO, White S (2009) The story of phosphorus: global food security and food for thought. Global Environ Chang 19(2):292-305

2. European Commission C5068 (2011) FP7 Cooperation Work Programme Theme 2: Food, Agriculture and Fisheries, and Biotechnologies. http://ec europa.eu/research/participants/data/ref/fp7/89419/b-wp-201201_en.pdf. Accessed 08 October 2014

3. FAO (2007) FAO yearbook of fishery statistics: aquaculture production 2005 FAO Yearbook of Fishery Statistics 100(2):202. vii

4. Chen Y, Aviad T (1990) Effects of humic substances on plant growth. In: MacCarthy P, Clapp CE, Malcolm RL, Bloom PR (ed) Humic sbstances in soil and crop sciences. Soil Science Society of America Inc, Madison, Wisconsin, USA

5. Anastas PT, Warner JC (1998) Green chemistry: theory and practice. Oxford University Press, Oxford

6. Kroyer GT (1998) Bioconversion of food processing wastes. In: Martin AM (ed) Bioconversion of waste materials to industrial products. Springer Science, Business Media, New York

7. Urs N, Anamarija S, Otto S, Niels H, Marco S (2008) Vision for an organic food and farming research agenda to 2025; organic knowledge for the future. Vision Research Agenda, European Technology Platforms (ETP). http://www.darcof.dk/research/grafikNVisions_08.pdf

8. EC (2007) Organic production and labelling of organic products and repealing regulation. 834. Official Journal of the European Union, The Council Of The European Union 91:23

9. Zhang S, Bi H, Liu C (2007) Extraction of bio-active components from Rhodiola sachalinensis under ultrahigh hydrostatic pressure. Sep Purif Technol 57(2):277-282

10. EPA (1996) Ecological effects test guidelines. Seed Germination/Root Elongation Toxicity Test, US Environmental Protection Agency. EPA. 712-C-96-154

11. IRSA-Istituto di Ricerca sulle Acque (1983) Analisi della fitotossicità della sostanza organica in decomposizione mediante bioassaggio Lepidium sativum. Metodi Analitici per i Fanghi: Parametri biochimici e biologici. Quaderno IRSA 64:8.1-8.3

12. Trinchera A, Leita L, Sequi P (2006) Metodi di Analisi per i Fertilizzanti. Istituto Sperimentale per la Nutrizione delle Piante per conto del Ministero delle politiche agricole alimentari e forestali, Roma, Italy

13. Bremner JM (1996) Nitrogen total. In: Sparks DL (ed) Methods of soil analysis. Soil Science Society of America, Madison, Wisconsin

14. Olsen SR, Sommers LE (1982) Phosphorus. In: Page AL, Miller RH (ed) Methods of Soil Analysis, Part 2. 2nd ed. Agronomy Monograph 9, ASA and SSSA, Madison, WI, USA

15. Fan TWM (1996) Metabolite profiling by one- and two-dimensional NMR analysis of complex mixtures. Prog Nucl Mag Res Sp 28(2):161-219

16. Nicholson JK, Foxall PJ, Spraul M, Farrant RD, Lindon LC (1995) $750 \mathrm{MHz}{ }^{1} \mathrm{H}$ and ${ }^{1} \mathrm{H}^{13} \mathrm{C}$ NMR spectroscopy of human blood plasma. Anal Chem 67(5):793-811

17. Mussatto SI, Roberto IC (2006) Chemical characterization and liberation of pentose sugars from brewers spent grain. J Chem Technol Biot 81(3):268-274

18. Khidzir K, Noorlidah A, Agamuthu P (2010) Brewery spent grain: chemical characteristics and utilization as an enzyme substrate. Malay J Sci 29(1):41-51 
19. Gupta M, Abu-Ghannam N, Gallaghar E (2010) Barley for brewing: characteristic changes during malting, brewing and applications of its by-products. Compr Rev Food Sci Food Saf 9(3):318-328

20. Kotlar CE, Belagardi M, Roura SI (2011) Brewer's spent grain: characterization and standardization procedure for the enzymatic hydrolysis by Bacillus cereus strain. Biotechnol Appl Bioc 58(6):464-475

21. Bianco W, Damato G, Girardi A (1994) Sowing dates, plant density and 'crown' cutting on yield and quality of florence fennel "seed". In: Quagliotti L, Belletti P (ed). Acta Hort 362:59-66

22. Muckensturm B, Foechterlen D, Reduron JP, Danton P, Hildenbrand M (1997) Phytochemical and chemotaxonomic studies of Foeniculum vulgare. Biochem Syst Ecol 25(4):353-358

23. Su HCF, Horvat R (1987) Isolation and characterization of four major components from insecticidally active lemon peel extract. J Agr Food Chem 35(4):509-511

24. USDA (2011) Nutrient lists. National Nutrient Database for Standard Reference, United States department of Agriculture. http://ndb.nal.usda.gov/ $\mathrm{ndb} /$ foods/show?fg=9\&man=\&lfacet=\&count $=\& \max =25 \&$ sort=f\&qlookup=\& offset=175\&format=Full\&new=\&rptfrm=n|\&ndbno=09156\&nutrient $1=301 \&$ nutrient2 $=309 \&$ nutrient $3=207 \&$ subset $=0 \&$ totCount $=336 \&$ measureby $=m$

25. Commission Decision 2006/799/EC (2006) Establishing revised ecological criteria and the related assessment and verification requirements for the award of the community eco-label to soil improvers. Official J L 325:28-34

26. Tian F, Li B, Ji B, Yang J, Zhang G, Chen Y, Luo Y (2009) Antioxidant and antimicrobial activities of consecutive extracts from Galla chinensis: the polarity affects the bioactivities. Food Chem 113(1):173-179

27. Kalia K, Sharma K, Singh HP, Singh B (2008) Effects of extraction methods on phenolic contents and antioxidant activity in aerial parts of Potentilla atrosanguinea Lodd. and quantification of its phenolic constituents by RP-HPLC. J Agr Food Chem 56(21):10129-10134

28. Taie HAA, Helal MMI, Helmy WA, Amer H (2013) Chemical composition and biological potentials of aqueous extracts of fennel (Foeniculum vulgare $\mathrm{L}$ ). J Appl Sci Res 9(3):1759-1767

29. Leal PF, Almeida TS, Prado GHC, Prado JM, Meireles MAA (2011) Extraction kinetics and anethole content of fennel (Foeniculum vulgare) and anise seed (Pimpinella anisum) extracts obtained by soxhlet, ultrasound, percolation, centrifugation, and steam distillation. Separ Sci Technol 46(11):1848-1856

30. H-Suk K, Mi-Ra Y, Ok-Hwan L, Suk-Nam K (2011) Antioxidant activities of hot water extracts from various spices. Int J Mol Sci 12(6):4120-4131

31. Kang HJ, Chawla SP, Jo C, Kwon JH, Byun MW (2006) Studies on the development of functional powder from citrus peel. Bioresource Technol 97(4):614-620

32. Zia-ur R (2006) Citrus peel extract-a natural source of antioxidant. Food Chem 99(3):450-454

33. Londoño-Londoño J, Lima VR, Lara O, Gil A, Pasa TBC, Arango GJ, Pineda JRR (2010) Clean recovery of antioxidant flavonoids from citrus peel: Optimizing an aqueous ultrasound-assisted extraction method. Food Chem 119(1):81-87

34. Tsibranska I, Tylkowski B, Kochanov R, Alipieva K (2011) Extraction of biologically active compounds from Sideritis ssp. L Food Bioprod Process 89(4):273-280

35. Kim WJ, Kim J, Veriansyah B, Kim JD, Lee YW, Oh SG, Tjandrawinata RR (2009) Extraction of bioactive components from Centella asiatica using subcritical water. J Supercrit Fluid 48(3):211-216

36. Gamiz-Gracia L, Luque de Castro MD (2000) Continuous subcritical water extraction of medicinal plant essential oil: comparison with conventional techniques. Talanta 51(6):1179-1185

37. Tubtimdee C, Shotipruk A (2011) Extraction of phenolics from Terminalia chebula Retz with water-ethanol and water-propylene glycol and sugaringout concentration of extracts. Sep Purif Technol 77(3):339-346

38. Katembe WJ, Ungar IA, Mitchell JP (1998) Effect of Salinity on Germination and Seedling Growth of two Atriplex species (Chenopodiaceae). Ann Bot 82(2):167-175

39. Redmann RE, Abouguendia ZM (1979) Germination and seedling growth on substrates with extreme $\mathrm{pH}$ : laboratory evaluation of buffers. J Appl Ecol 16(3):901-907

40. Politycka B, Wójcik-Wojtkowiak D, Pudelski T (1985) Phenolic compounds as a cause of phytotoxicity in greenhouse substrates repeatedly used in cucumber growing. Acta Hort 156:89-94

41. Stalikas CD (2007) Extraction, separation, and detection methods for phenolic acids and flavonoids. J Sep Sci 30(18):3268-3295

42. Naczk M, Shahidi F (2004) Extraction and analysis of phenolics in food. J Chromatogr A 1054(1-2):95-111

43. Shahidi F, Daun JK, DeClercq DR (1997) Glucosinolates in Brassica oilseeds: processing effects and extraction. In: Antinutrients and Phytochemicals in
Food. ACS Symposium Series. American Chemical Society. http://pubs.acs. org/doi/abs/10.1021/bk-1997-0662.ch009

44. Munir O, Ilhami G, I'Rfan OK (2010) Determination of in vitro antioxidant activity of fennel (Foeniculum vulgare) seed extracts. LWT-Food Sci Technol 36(2):263-271

45. Parejo I, Jauregui O, Sanchez-Rabaneda F, Viladomat F, Bastida J, Codina C (2004) Separation and characterization of phenolic compounds in fennel (Foeniculum vulgare) using liquid chromatography-negative electrospray ionization tandem mass spectrometry. J Agr Food Chem 52(12):3679-3687

46. Paari A, Naidu HK, Kanmani P, Satishkumar R, Yuvaraj N, Pattukumar V, Arul V (2012) Evaluation of irradiation and heat treatment on antioxidant properties of fruit peel extracts and its potential application during preservation of goat fish Parupenaeus indicus. Food Bioprocess Technol 5(5):1860-1870

47. Ward JL, Baker JM, Beale MH (2007) Recent applications of NMR spectroscopy in plant metabolomics. FEBS J 274(5):1126-1131

48. Nicholson JK, Wilson ID (1989) High-resolution proton magnetic resonance spectroscopy of biological fluids. Prog Nucl Magn Reson Spectrosc 21(4-5):449-501

49. Del Coco L, Assfalg M, D'Onofrio M, Sallustio F, Pesce F, Fanizzi FP, Schena FP (2013) A proton nuclear magnetic resonance-based metabolomic approach in IgA nephropathy urinary profiles. Metabolomics 9(3):740-751

50. Godelmann R, Fang F, Humpfer E, Scütz B, Bansbach M, Schäfer H, Spraul M (2013) Targeted and nontargeted wine analysis by ${ }^{1} H$ NMR spectroscopy combined with multivariate statistical analysis. Differentiation of important parameters: Grape variety, geographical origin, year of vintage. J Agric Food Chem 61(23):5610-5619

51. Del Coco L, De Pascali SA, Fanizzi FP (2014) ${ }^{1} \mathrm{H}$ NMR spectroscopy and multivariate analysis of monovarietal EVOOs as a tool for modulating Coratina-based blends. Foods 3(2):238-249

52. De Pascali SA, Coletta A, Del Coco L, Basile T, Gambacorta G, Fanizzi FP (2014) Viticultural practice and winemaking effects on metabolic profile of Negroamaro. Food Chem 161:112-119

53. Bohme M (1999) Effects of lactate, humate and Bacillus subtilis on the growth of tomato plants in hydroponic systems. Acta Hort 481:231-239

54. Bohme M, Ouahid A, Shaban N (2000) Reaction of some vegetable crops to treatments with lactate as bioregulator and fertilizer. Acta Hort 514:33-40

55. Pracharoenwattana I, Zhou WX, Keech O, Francisco PB, Udomchalothorn T, Tschoep H, Stitt M, Gibon Y, Smith SM (2010) Arabidopsis has a cytosolic fumarase required for the massive allocation of photosynthate into fumaric acid and for rapid plant growth on high nitrogen. Plant J 62(5):785-795

56. Mussatto S (2009) Biotechnological potential of brewing industry byproducts. In: Nigam P, Pandey A (ed) Biotechnology for agro-industrial residues utilisation. Springer, Netherlands

57. Huige N (1994) Brewery by-products and effluents. In: Wa H (ed) Handbook of brewing. Marcel Dekker, New York

58. Santos M, Jiménez JJ, Bartolomé B, Gómez-Cordovés C, del Nozal MJ (2003) Variability of brewer's spent grain within a brewery. Food Chem 80(1):17-21

59. Madhujith T, Shahidi F (2007) Antioxidative and antiproliferative properties of selected barley (Hordeum vulgarae L.) cultivars and their potential for inhibition of low-density lipoprotein (LDL) cholesterol oxidation. J Agr Food Chem 55(13):5018-5024

60. Jan A, Nakamura H, Handa H, Ichikawa H, Matsumoto H, Komatsu S (2006) Gibberellin regulates mitochondrial pyruvate dehydrogenase activity in rice. Plant Cell Physiol 47(2):244-253

61. Yu H, Du X, Zhang F, Zhang F, Hu Y, Liu S, Jiang X, Wang G, Liu D (2012) A mutation in the $E 2$ subunit of the mitochondrial pyruvate dehydrogenase complex in Arabidopsis reduces plant organ size and enhances the accumulation of amino acids and intermediate products of the TCA Cycle. Planta 236(2):387-399

62. Mandalari G, Bennett RN, Bisignano G, Saija A, Dugo G, Lo Curto RB, Faulds CB, Waldron KW (2006) Characterization of flavonoids and Pectins from bergamot (Citrus bergamia Risso) peel, a major byproduct of essential oil extraction. J Agr Food Chem 54(1):197-203

63. Poli A, Anzelmo G, Fiorentino G, Nicolaus B, Tommonaro G, Donato PD (2011) Polysaccharides from wastes of vegetable industrial processing: new opportunities for their eco-friendly re-use. In: Elnashar M (ed) Biotechnology of Biopolymers. InTech publication. doi:10.5772/16387 
64. Jones D (1998) Organic acids in the rhizosphere-a critical review. Plant Soil 205(1):25-44

65. Dennis DT, Turpin DH, Lefebvre DD, Layzell DB (1997) Plant metabolism. Addison Wesley Longman Ltd, Harlow UK. Plant metabolism

66. Sun YL, Hong SK (2011) Effects of citric acid as an important component of the responses to saline and alkaline stress in the halophyte Leymus chinensis (Trin.). Plant Growth Regul 64(2):129-139

doi:10.1186/s40538-014-0017-x

Cite this article as: Al Chami et al.: Extraction and characterization of bio-effectors from agro-food processing by-products as plant growth promoters. Chemical and Biological Technologies in Agriculture 2014 1:17.

Submit your manuscript to a SpringerOpen ${ }^{\circ}$ journal and benefit from:

- Convenient online submission

- Rigorous peer review

- Immediate publication on acceptance

- Open access: articles freely available online

- High visibility within the field

- Retaining the copyright to your article

Submit your next manuscript at springeropen.com 